\title{
TAMING CAPITAL FLOWS
}

Capital Account Management in an Era of Globalization

Edited by Joseph E. Stiglitz and Refet S. Gürkaynak

LIFE AFTER DEBT

The Origins and Resolutions of Debt Crisis

Edited by Joseph E. Stiglitz and Daniel Heymann

INCOME CONTINGENT LOANS

Theory, Practice and Prospects

Edited by Joseph E. Stiglitz, Bruce Chapman and Timothy Higgins

THE INDUSTRIAL POLICY REVOLUTION I

The Role of Government Beyond Ideology

Edited by Joseph E. Stiglitz and Justin Lin Yifu

THE INDUSTRIAL POLICY REVOLUTION II

Africa in the 21st Century

Edited by Joseph E. Stiglitz, Justin Lin Yifu and Ebrahim Patel

THE CHINESE ECONOMY

A New Transition

Edited by Masahiko Aoki and Jinglian Wu

INSTITUTIONS AND COMPARATIVE ECONOMIC DEVELOPMENT

Edited by Franklin Allen, Masahiko Aoki, Nobuhiro Kiyotaki, Roger Gordon, Joseph E.

Stiglitz and Jean-Paul Fitoussi

COMPLEXITY AND INSTITUTIONS: MARKETS, NORMS AND CORPORATIONS

Edited by Masahiko Aoki, Kenneth Binmore, Simon Deakin and

Herbert Gintis

CORPORATE SOCIAL RESPONSIBILITY AND CORPORATE GOVERNANCE

The Contribution of Economic Theory and Related Disciplines

Edited by Lorenzo Sacconi, Margaret Blair, R. Edward Freeman and Alessandro Vercelli

IS ECONOMIC GROWTH SUSTAINABLE?

Edited by Geoffrey Heal

KEYNE'S GENERAL THEORY AFTER SEVENTY YEARS

Edited by Robert Diman, Robert Mundell and Alessandro Vercelli

CORRUPTION, DEVELOPMENT AND INSTITUTIONAL DESIGN

Edited by János Kornai, László Mátyás and Gérard Roland

MARKET AND SOCIALISM

In the Light of the Experience of China and Vietnam

Edited by János Kornai and Yingyi Quian

INSTITUTIONAL CHANGE AND ECONOMIC BEHAVIOUR

Edited by János Kornai, László Mátyás and Gérard Roland

INTERGENERATIONAL EQUITY AND SUSTAINABILITY

Edited by John E. Roemer and Kotaro Suzumura 
PSYCHOLOCY, RATIONALITY AND ECONOMIC BEHAVIOUR

Challenging Standard Assumptions

Edited by Bina Agarwal and Alessandro Vercelli

MULTINATIONALS AND FOREIGN INVESTMENT IN ECONOMC DEVELOPMENT

Edited by Edward M. Graham

POST-CONFLICT ECONOMIES IN AFRICA

Edited by Paul Collier and Augustin Kwasi Fosu

STRUCTURAL REFORM AND MACROECONOMIC POLICY

Edited by Robert M. Solow

THE PAST, PRESENT AND FUTURE OF THE EUROPEAN UNION

Edited by Alan V. Deardorff

\section{LATIN AMERICAN ECONOMIC CRISES}

Trade and Labour

Edited by Enrique Bour, Daniel Heymann and Fernando Navajas

ADVANCES IN MACROECONOMIC THEORY

Edited by Jacques H, Drèze

EXPLAINING GROWTH

A Global Research Project

Edited by Gary McMahon and Lyn Squire

TRADE, INVESTMENT, MIGRATION AND LABOUR MARKET ADJUSTMENT

Edited by David Greenaway, Richard Upward and Katherine Wakelin

INEQUALITY AROUND THE WORLD

Edited by Richard B. Freeman

MONETARY THEORY AND POLICY EXPERIENCE

Edited by Axel Leijonhufvud

MONETARY THEORY AS A BASIS FOR MONETARY POLICY

Edited by Axel Leijonhufvud

ECONOMIC DEVELOPMENT IN SUBSAHARAN AFRICA

Proceedings of the Eleventh World Congress of the International Economic Association, Tunis Edited by Ibrahim Elbadawi and Beno Ndula

ECONOMIC DEVELOPMENT IN SUBSAHARAN AFRICA

Proceedings of the Eleventh World Congress of the International Economic Association, Tunis

Edited by Ibrahim Elbadawi and Beno Ndula

\footnotetext{
International Economics Association

Series Standing Order ISBN 978-0-3337-1242-9 (Hardback)

978-0-3338-0330-1 (Paperback)
}

You can receive future titles in this series as they are published by placing a standing order. Please contact your bookseller or, in case of difficulty, write to us at the address below with your name and address, the title of the series and one of the ISBNs quoted above.

Customer Services Department, Macmillan Distribution Ltd, Houndmills, Basingstoke, Hampshire RG21 6XS, England 


\section{palgrave»pivot}

\section{Taming Capital Flows: Capital Account Management in an Era of Globalization}

IEA Conference Volume No. 154

Edited by

Joseph E. Stiglitz

University Professor, Columbia University, USA

and

Refet S. Gürkaynak

Professor of Economics, Department of Economics, Bilkent University, Turkey

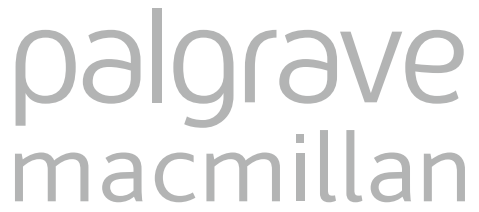




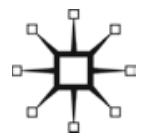

Selection and editorial matter () Joseph E. Stiglitz and Refet S. Gürkaynak 2015 Individual chapters ( $)$ contributors 2015

Softcover reprint of the hardcover 1st edition 2015 978-1-137-42766-3

All rights reserved. No reproduction, copy or transmission of this publication may be made without written permission.

No portion of this publication may be reproduced, copied or transmitted save with written permission or in accordance with the provisions of the Copyright, Designs and Patents Act 1988, or under the terms of any licence permitting limited copying issued by the Copyright Licensing Agency, Saffron House, 6-10 Kirby Street, London EC1N 8TS.

Any person who does any unauthorized act in relation to this publication may be liable to criminal prosecution and civil claims for damages.

The authors have asserted their rights to be identified as the authors of this work in accordance with the Copyright, Designs and Patents Act 1988.

First published 2015 by PALGRAVE MACMILLAN

Palgrave Macmillan in the UK is an imprint of Macmillan Publishers Limited, registered in England, company number 785998, of Houndmills, Basingstoke, Hampshire RG21 6XS.

Palgrave Macmillan in the US is a division of St Martin's Press LLC, 175 Fifth Avenue, New York, NY 10010.

Palgrave Macmillan is the global academic imprint of the above companies and has companies and representatives throughout the world.

Palgrave $^{\oplus}$ and Macmillan ${ }^{\circledR}$ are registered trademarks in the United States, the United Kingdom, Europe and other countries.

ISBN: 978-1-137-42768-7 PDF

ISBN: 978-1-349-49121-6

A catalogue record for this book is available from the British Library.

A catalog record for this book is available from the Library of Congress.

www.palgrave.com/pivot

DOI: $10.1057 / 9781137427687$ 


\section{Contents}

List of Illustrations vii

Notes on Contributors $\quad$ x

Introduction 1

Part 1 Country Experiences

1.1 Peru's Recent Experience in Managing

Capital Flows

Paul Castillo B.

1.2 The Turkish Approach to Capital

Flow Volatility

Yasin Akçelik, Erdem Baş̧̧ı, Ergun Ermişoğlu, and Arif Oduncu

Part 2 Recent Trends in Currency Flows

2.1 The Liberalization of Capital Account in China: Retrospect and Prospect

Ming Zhang

2.2 Appropriate Policy Tools to Manage

Capital Flow Externalities

Refet S. Gürkaynak

2.3 Navigating Capital Flows in Brazil and Chile

Brittany A. Baumann and Kevin P. Gallagher 
Part 3 Effects and Multilateral Aspects of Currency Flows

3.1 Monetary Policy in a Multi-Polar World

Joseph E. Stiglitz

3.2 Managing Capital Flows - Capital

Controls and Foreign Exchange Intervention

Jonathan D. Ostry

Index 


\section{List of Illustrations}

\section{Box}

3.2.1 A simple dynamic model of an emerging market economy

\section{Figures}

1.1.1 Capital flows to Peru: 1991-2001 11

1.1.2 Capital flows to Peru: 1995-2012 12

1.1.3 Net international reserves 17

1.1.4 Public debt: Peru 18

1.1.5 Public debt: Peru 18

1.1.6 External liabilities of banking institutions 20

1.1.7 Foreign currency reserve ratios 21

1.1.8 Peru selected indicators 23

1.2.1 Volatility in risk appetite 33

1.2.2 Fund flows to EMs 33

1.2.3 Excess reserves held in central banks $\quad 36$

1.2.4 Global growth rates 37

1.2.5 Capital flows and GDP growth in Turkey 39

1.2.6 Current account deficit and credit growth 40

1.2.7 Sources of external finance 40

1.2.8 Monetary policy and interest rates 41

1.2.9 TL and emerging market currencies 42

1.2.10 Real effective exchange rate in Turkey 42

1.2.11 Sources of external finance 43

1.2.12 Monetary policy and interest rates 44

1.2.13 Exports and imports index 45 
1.2.14 Current account deficit 45

1.2.15 Inflation expectations and realizations 46

1.2.16 Monetary policy and interest rates 47

1.2.17 Reserve options mechanism $\quad 47$

1.2.18 Reserve options mechanism 48

1.2.19 FX reserves 48

1.2.20 Gold reserves 49

1.2.21 New borrowing 49

1.2.22 FX implied volatility and current account 50

1.2.23 FX implied volatility and current account 50

2.1.1 The contribution to annual reserve accumulation in China $\quad 59$

2.1.2 The gross and net cross-border flows in China 60

2.1.3 The decomposition of China's financial account 61

2.1.4 China's FDI and ODI 61

2.1.5 China's inward and outward portfolio investment 62

2.1.6 China's foreign debt and its structure 63

2.1.7 The net error and omission of China's balance of payment $\quad 63$

$\begin{array}{lll}2.3 .1 & \text { BRL } & 100\end{array}$

$\begin{array}{ll}2.3 .2 & \text { Bovespa } \\ & 100\end{array}$

2.3.3 Brazil net inflows 100

$\begin{array}{ll}\text { 2.3.4 Chilean peso } & 103\end{array}$

$\begin{array}{ll}\text { 2.3.5 Santiago stock exchange } & 103\end{array}$

3.2.1 Policy responses to manage inflow surges $\quad 178$

3.2.2 Choice of instruments: flows intermediated
through the financial sector

3.2.3 Choice of instruments: flows not intermediated $\begin{array}{ll}\text { through the financial sector } & 180\end{array}$

3.2.4 Policy response to a capital inflow shock 188

\section{Tables}

1.1.1 Holdings of non-residents of domestic assets 13

$\begin{array}{ll}\text { 1.1.2 Indicators of international soundness } & 17\end{array}$

1.1.3 Non-resident holdings of Peruvian fixed-income assets 22

$\begin{array}{ll}\text { 1.1.4 Capital flows to Peru } & 27\end{array}$

$\begin{array}{ll}\text { 1.1.5 Capital flows to Peru } & 28\end{array}$ 
2.1.1 The current state of China's capital account openness

2.1.2 The capital account liberalization measures adopted to promote $\mathrm{RMB}$ internationalization

2.1.3 The reform of RMB exchange rate regime 75

2.3.1 Summary of measures to manage capital flows in Brazil and Chile

2.3.2 Capital account regulations in Brazil, 2009-2012 102

2.3.3 Currency market intervention in Chile, 2010-2011 104

2.3.4 Brazilian real 111

2.3.5 Chilean peso 112

$\begin{array}{ll}\text { 2.3.6 Brazilian stock exchange } & 113\end{array}$

$\begin{array}{ll}\text { 2.3.7 Chilean stock exchange } & 114\end{array}$

2.3.8 Brazil long-term and short-term net inflows 115

2.3.9 Brazil total, non-FDI, and FDI net inflows 116

2.3.10 Total, non-FDI, and FDI net inflows 117

2.3.11 Chilean net inflows and spillover effects 117

3.2.1 Taylor rules in emerging market inflation targeters: $\begin{array}{ll}\text { panel regression } & 183\end{array}$

3.2.2 Change in reserves as a function of the change in the REER

3.2.3 Studies on sterilized intervention in emerging market economies 


\section{Notes on Contributors}

Yasin Akçelik received a BA in Economics from Bilkent University in 2004. He obtained his MA and $\mathrm{PhD}$ degrees in Economics from Ohio State University in 2006 and 2011, respectively. He received a university scholarship at Bilkent University and a university fellowship and Departmental Citation for Excellence in Teaching and Graduate Associate Teaching Awards at Ohio State. He worked as a research and teaching assistant and taught classes on international trade and development economics as an instructor at Ohio State. He also worked as a consultant in the Credit Risk Modeling Department at JPMorgan Chase Bank in 2006. He joined the Central Bank of the Republic of Turkey as an economist in 2011. His research focus is monetary economics, international trade and political economy.

Erdem Başçı earned his PhD in Economics from Bilkent University in 1995 . His research and teaching areas during his academic tenure were monetary economics, financial economics, macroeconomic theory and mathematical economics. Başçı's papers have been published in Oxford Economic Papers, Journal of Banking and Finance, Journal of Economic Dynamics and Control and Journal of Mathematical Economics. During his first term as a deputy governor of the Central Bank of the Republic of Turkey, he served as a G2o deputy while also being in charge of the banking and financial institutions department. In his second term as a deputy, he was responsible for the research and monetary policy department and the statistics department. Başçı was appointed as the governor on 19 April 2011. 
Brittany A. Baumann is a recent $\mathrm{PhD}$ graduate in Economics at Boston University and currently works as an economist at The Clearing House Association in New York.

Paul Castillo B. is Deputy Manager of Monetary Policy at the Central Bank of Peru. He holds a PhD in Economics from the London School of Economics, and he is also Professor of Economics at Pontificia Universidad Católica del Perú. He has produced research on dollarization and its effects on monetary policy, informal labor markets and its consequences on inflation dynamics, and on models for studying monetary policy in small open economies.

Ergun Ermişoğlu earned a BA in Economics from the Boğaziçi University in 2003. He received his MA in Applied Economics from the University of Michigan in 2010. He now continues his PhD in Banking and Finance in Yıldirım Beyazit University. He worked as an assistant auditor at the Turkish Court of Accounts, before joining the Central Bank of the Republic of Turkey (CBRT) as an assistant specialist. He now works as a specialist at the governor's office at CBRT. Monetary economics, financial economics, banking and macroeconomic theory are his research areas.

Kevin P. Gallagher is Associate Professor of International Relations at Boston University where he co-directs the Global Economic Governance Initiative.

Refet S. Gürkaynak is Professor of Economics at Bilkent University and a research fellow of the Center for Economic Policy Research, Center for Financial Studies and CESIfo. He has a BA from Bilkent and a PhD from Princeton Universities, both in Economics. Gürkaynak's research interests are monetary economics, financial markets and international economics. In particular, he works on extracting information from asset prices that help answer monetary policy related questions.

Joseph E. Stiglitz is University Professor at Columbia University. In 2001, he was awarded the Nobel Prize in Economics for his analyses of markets with asymmetric information. He was the President of the International Economic Association from 2011 to 2014.

Arif Oduncu received his BS in Electrical Engineering (summa cum laude, high honors) in 2003 and MS in Electrical Engineering in 2004 
from Texas A\&M University. He obtained his MS in Economics in 2006 and $\mathrm{PhD}$ in Economics in 2009 from University of Texas at Austin. He has received Regents' Graduate Fellowship, Undergraduate Research Fellowship and Texas A\&M Academic Excellence Awards. He was a summer associate at the Projections and Modeling Unit at the US Congressional Budget Office in summer 2006. He worked as a teaching assistant at the University of Texas at Austin before joining the Central Bank of Turkey as an economist. His research areas are macroeconomics, financial economics and monetary economics.

Jonathan D. Ostry is a deputy director of the research department (RES) at the International Monetary Fund. His current responsibilities include leading staff teams on IMF-FSB Early Warning Exercises on global systemic macrofinancial risks; multilateral exchange rate surveillance; international financial architecture and capital account management; and fiscal sustainability issues. Past positions include leading the division that produces the IMF's flagship multilateral surveillance publication, the World Economic Outlook, and leading country teams on Australia, Japan, New Zealand, and Singapore. Ostry is the author/editor of a number of books on international macro policy issues, and numerous articles in scholarly journals. He holds undergraduate degrees from the University of Oxford (Balliol College) and Queen's University (Canada), and graduate degrees from the London School of Economics (MSc, 1984) and the University Chicago ( $\mathrm{PhD}, 1988)$.

Ming Zhang is a senior research fellow and the director of the Department of International Investment, Institute of World Economics and Politics (IWEP) under the Chinese Academy of Social Science (CASS). His research covers international finance and Chinese macroeconomy. In the past several years, his fields of interest include global financial crisis, foreign exchange reserves, cross-border capital flow, RMB's exchange rate and internationalization. He has produced 10 books, more than 80 academic papers, and numerous articles. Before joining IWEP, he worked as an auditor in KPMG, and a PE fund manager in Asset Managers Group (Japan). He received his doctor's degree from the Graduate School of CASS. 